\title{
Selection of glufosinate-resistant cotton lines (Gossypium hirsutum L.) among bar transgenic lines
}

\author{
Nha T. Nguyen ${ }^{1,2 *}$, Tri M. Bui ${ }^{3}, \&$ Kiem T. Phan $^{1}$ \\ ${ }^{1}$ Faculty of Biotechnology, Nguyen Tat Thanh University, Ho Chi Minh City, Vietnam \\ ${ }^{2}$ Department of Biotechnology, Nong Lam University, Ho Chi Minh City, Vietnam \\ ${ }^{3}$ Faculty of Agriculture, Nong Lam University, Ho Chi Minh City, Vietnam
}

\begin{abstract}
ARTICLE INFO
Research Paper

Received: September 11, 2020

Revised: October 08, 2020

Accepted: October 24, 2020
\end{abstract}

Keywords

Bar gene

Gossypium hirsutum L.

Glufosinate tolerance

Transgenic cotton

${ }^{*}$ Corresponding author

Nguyen Thi Nha

Email: ntnha@ntt.edu.vn

\begin{abstract}
Basta-herbicide was tested at a concentration of $0.6 \mathrm{~kg}$ ai./ha for confirming resistance of 116 bar transgenic $\mathrm{T}_{1}$ lines; many lines with tolerance were obtained. Evaluation of selected lines using PCR, the integration and expression of transgenes in genome of transgenic plants was determined by southern blot and northern blot techniques. The combination of molecular and biological assessments resulted in the selection of 5 lines, i.e., B1, B6, B9, B18, and BF17 contained 01 target-gene copy which expressed transcription activities and showed uniform growth and best tolerance to glufosinate. Two $\mathrm{T}_{2}$ transgenic cotton lines, i.e., B9 and BF17, carried one copy of the gene which transmitted to the next generation according to the Mendel's rules of inheritance. These transgenic lines were highly resistant to Basta herbicide at a concentration of $0.6 \mathrm{~kg}$ ai./ha and had no difference in botanical characteristics and disease resistance in comparison with original non-transgenic Coker310 cotton plant.
\end{abstract}

Cited as: Nguyen, N. T., Bui, T. M., \& Phan, K. T. (2020). Selection of glufosinate-resistant cotton lines (Gossypium hirsutum L.) among bar transgenic lines. The Journal of Agriculture and Development 19(5), 71-79. 


\title{
Chọn lọc các dòng bông (Gossypium hirsutum L.) chuyển gen bar chống chịu thuốc
}

\author{
Nguyễn Thị Nhã ${ }^{1,2 *}$, Bùi Minh Trî́ $i^{3} \&$ Phan Thanh Kiếm ${ }^{1}$ \\ ${ }^{1}$ Khoa Công Nghệ Sinh Học, Trường Đại Học Nguyễn Tất Thành, TP. Hồ Chí Minh \\ ${ }^{2}$ Bộ Môn Công Nghệ Sinh Học, Trường Đại Học Nông Lâm TP.HCM, TP. Hồ Chí Minh \\ ${ }^{3}$ Khoa Nông Học, Trường Đại Học Nông Lâm TP.HCM, TP. Hồ Chí Minh
}

\section{THÔNG TIN BÀI BÁO}

Bài báo khoa học

Ngày nhận: 11/09/2020

Ngày chỉnh sửa: 08/10/2020

Ngày chấp nhận: 24/10/2020

\section{Từ khóa}

Bông chuyển gen

Chống chịu glufosinate

Gen bar

Gossypium hirsutum L.

*Tác giả liên hệ

Nguyễn Thị Nhã

Email: ntnha@ntt.edu.vn

\section{TÓM TẮT}

Thử khả năng chống chịu thuốc diệt cỏ Basta ở nồng độ $0,6 \mathrm{~kg}$ ai./ha cho 116 dòng $T_{1}$ chuyển gen bar thu được các dòng chống chịu. Đánh giá bằng kỹ thuật $\mathrm{PCR}$, Southern blot và northern blot đã xác định được sự hiện diện, sự gắn kết và biểu hiện của gen chuyển trong genome cây chuyển gen. Chọn được 05 dòng $\mathrm{B} 1, \mathrm{~B} 6, \mathrm{~B} 9, \mathrm{~B} 18$ và $\mathrm{BF} 17$ mang 1 bản sao, có hoạt động phiên mã của gen chuyển, cây sinh trưởng đồng đều và có mức độ chống chịu thuốc diệt cỏ glufosinate cao. Trong đó, 02 dòng bông chuyển gen $\mathrm{T}_{2}$ là $\mathrm{B} 9$ và $\mathrm{BF} 17$ mang 01 bản sao gen, di truyền gen chuyển theo quy luật Mendel, chống chịu cao với thuốc trừ cỏ Basta ở nồng độ $0,6 \mathrm{~kg}$ ai./ha, không sai khác về đặc điểm thực vật học và không sai khác về khả năng chống chịu bệnh hại so với giống bông nền Coker310 không chuyển gen.

\section{1. Đặt Vấn Đề}

Cùng với sâu bệnh, cỏ dại là một trong những tác nhân quan trọng làm giảm năng suất, sản lượng và phẩm chất cây trồng. Trong số các biện pháp phòng trừ thì biện pháp hóa học hay nói cách khác là sử dụng các loại thuốc diệt cỏ đã, đang và luôn là biện pháp đạt hiệu quả nhanh chóng và phổ biến. Hiện nay, bằng kỹ thuật chuyển các gen chống chịu thuốc diệt cỏ vào cây trồng đã mở ra kỷ nguyên mới có tính chất đột phá cho nền nông nghiệp.

Trên thế giới, bông (Gossypium sp.) là cây trồng kinh tế lấy sợi tự nhiên quan trọng. Việt Nam cũng có tiềm năng lớn trong sản xuất bông, chấp thuận cây bông biến đổi gen vì hiện là nước phát triển nhanh nhất về công nghiệp dệt may (FAO, 2018). Nguồn cung bông trong nước chỉ cung cấp dưới $1 \%$ nhu cầu và thậm chí nhập khẩu
100\% bông trong tương lai gần (USDA, 2019). Vì thế, sản xuất bông Việt Nam rất cần giống có hiệu quả kinh tế và giải quyết vấn đề nhân lực. Như vậy, việc ứng dụng kỹ thuật chuyển gen tạo giống bông chống chịu thuốc diệt cỏ là phù hợp và hiện đã có nhiều dòng chuyển gen bar được tạo ra (Nha \& ctv., 2016).

Để phát triển các dòng bông chuyển gen nêu trên đánh giá và chọn lọc. Ở mức phân tử xác định sự có mặt và gắn kết gen chỉ là điều kiện cần, còn tính chịu thuốc trừ cỏ trên điều kiện đồng ruộng mới là điều kiện đủ. Tính chịu thuốc trừ cỏ có thể không tương quan với số bản sao gen chuyển nhưng lại có quan hệ với vị trí gắn và mức độ biểu hiện của gen chuyển (Elbaidouri \& ctv., 2013). Do đó, phân tích sinh học bổ sung cần được thực hiện để chọn lọc được dòng bông chuyển gen chịu thuốc trừ cỏ cao, không bị phân ly qua các thế hệ. Bài báo này trình bày kết quả 
đánh giá và chọn lọc cây bông chuyển gen bar chống chịu thuốc diệt cỏ gốc glufosinate.

\section{Vật Liệu và Phương Pháp Nghiên Cứu}

\subsection{Vật liệu nghiên cứu}

Gồm 47 cây T0 chuyển gen pCB301: bar và 69 cây T0 chuyển gen pCAMBIA: bar.

Là sản phẩm kế thừa từ nhóm nghiên cứu (Nha \& ctv., 2016).

\subsection{Phương pháp nghiên cứu}

\subsubsection{Tách chiết, tinh sạch DNA và RNA tổng số}

DNA tổng số của cây bông được tách chiết từ lá non theo quy trình của $\mathrm{Li}$ và ctv ( $\mathrm{Li} \&$ ctv., 2001). Nghiền 100 mg lá non trong nitơ lỏng, bổ sung $500 \mu \mathrm{L}$ dung dịch CTAB 2\% (chứa RNase) và ly tâm ở tốc độ 13.000 vòng/phút trong 15 phút để thu dịch nổi. Kết tủa protein bằng $500 \mu \mathrm{L}$ chloroform: isoamyl (24:1) và tủa DNA bằng 50 $\mu \mathrm{L}$ isopropanol. Kiểm tra chất lượng DNA tổng số trên gel agarose $0,8 \%$ và xác định nồng độ trên máy quang phổ.

RNA tổng số của cây chuyển gen tách chiết từ lá non theo quy trình Trizol regent (cat. 10296010, Invitrogen, Mỹ). 200 mg lá non được nghiền nhanh trong nitơ lỏng, bổ sung ngay 750 $\mu \mathrm{L}$ trizol, li tâm 13.000 vòng/phút trong 10 phút thu dịch nổi, kết tủa protein bằng $500 \mu \mathrm{L}$ chloroform. Thu dịch nổi và tủa với $20 \mu \mathrm{L}$ isopropanol và để thu RNA tổng số. Kiểm tra chất lượng RNA trên gel agarose $1 \%$ biến tính bằng formaldehyde và xác định nồng độ trên máy quang phổ.

\subsubsection{PCR xác định sự hiện diện của gen chuyển trong cây chuyển gen}

Phản ứng PCR nhân phân đoạn DNA 440 bp đặc hiệu của gen bar bằng cặp primer barF 5'-GTCTGCACCATCGTCAACC3' và barR 5'-GAAGTCCAGCTGCCAGAAAC3'. Thành phần gồm $10 \mu \mathrm{L} 2 \mathrm{X}$ GoTaq $^{\circledR} \mathrm{G} 2$ Green Master Mix (Taq DNA Polymerase, 400 $\mu \mathrm{M}$ dATP, $400 \mu \mathrm{M}$ dGTP, $400 \mu \mathrm{M}$ dCTP, $400 \mu \mathrm{M}$ dTTP và $\left.3 \mathrm{mM} \mathrm{MgCl}_{2}\right) ; 1 \mu \mathrm{L}$ mồi $(10 \mathrm{pM} / \mu \mathrm{L})$; $2 \mu \mathrm{L}(50 \mathrm{ng} / \mu \mathrm{L})$ DNA khuôn; thêm $\mathrm{H}_{2} \mathrm{O}$ đến thể tích $20 \mu \mathrm{L} /$ phản ứng. Chu trình nhiệt gồm, tiền biến tính $94^{\circ} \mathrm{C}$ : 5 phút (1 chu kỳ); biến tính $94^{\circ} \mathrm{C}$ : 60 giây, bắt cặp $55^{\circ} \mathrm{C}$ : 30 giây, kéo dài $72^{\circ} \mathrm{C}$ : 60 giây (35 chu kỳ); kêt thúc $72^{\circ} \mathrm{C}$ : 5 phút (1 chu kỳ). Kết quả xác định trên điện di đồ, xuất hiện băng có thước tương đương trên ĐC $(+)$ : gen có mặt trong tế bào; không xuất hiện băng: không có gen trong tế bào.

\subsubsection{Tạo mẫu dò}

Mẫu dò để lai DNA/DNA là sản phẩm PCR nhân gen bar được đánh dấu theo kít "DIG high prime DNA labeling and detection starter kit II" (cat. 11585614910, Roche, Đức). Mẫu dò để lai DNA/RNA là sản phẩm PCR nhân gen bar theo kít "DIG Northern starter" (cat. 12039672910, Roche, Đức).

\subsubsection{Southern blot}

Cắt plasmid $(Đ C+)$ bằng cặp enzyme PstI, EcoRI để tạo ra phân đoạn DNA mục tiêu. Cắt $20 \mu \mathrm{g}$ DNA tổng số của các cây chuyển gen thế hệ $\mathrm{T}_{1}$ và giống gốc không chuyển gen ( $\mathrm{DC}$-) bằng enzyme EcoRI để tạo ra các phân đoạn DNA có kích thước khác nhau. Điện di sản phẩm cắt trên gel agarose $0,8 \%$ qua đêm. Thấm truyền DNA lên màng lai (Amersham, Anh), lai và dò tìm theo hướng dẫn. Kết quả xác định trên film X-Ray có xuất hiện băng lai: có gen gắn kết; không xuất hiện băng lai: không có gen gắn kết với genome.

\subsubsection{Northern blot}

10 g RNA được phân tách băng rRNA trên gel agarose $1,2 \%$ bồ sung formaldehyde $37 \%$. Thấm truyền RNA lên màng nylon theo quy trình "DIG Northern starter". Tiến hành phép lai với mẫu dò đã được đánh dấu. Kết quả xác định trên film XRay, xuất hiện băng lai: có hoạt động phiên mã; không xuất hiện băng lai: không có hoạt động phiên mã.

\subsection{6. Đánh giá tính chống chịu thuốc trừ cỏ}

Các dòng bông chuyển gen được gieo trồng trong nhà lưới, không sử dụng các biện pháp phòng trừ cỏ khác. Ở giai đoạn cây 5-10 lá (khi cỏ mọc rất tốt), tiến hành phun thuốc trừ cỏ Basta 15SL ở nồng độ $0,6 \mathrm{~kg}$ ai./ha. Đánh giá mức độ tổn thương của cây bông chuyển gen và cây không chuyển gen ở giai đoạn 7 ngày sau phun. Tổn thương nhìn mắt thường được tính toán dựa trên quan sát triệu chứng ố vàng và hoại tử của cây bông bị xử lý thuốc với quy ước:

Chống chịu rất cao $(+++++):<1 \%$ diện tích 
lá bị hoại tử

Chống chịu cao $(++++)$ : $1-5 \%$ diện tích lá bị hoại tử

Chống chịu trung bình $(+++):>5-25 \%$ diện tích lá bi hoại tử

Chống chịu kém $(++)$ : > 25 - 50\% diện tích lá bị hoại tử

Chống chịu rất kém $(+):>50 \%$ diện tích lá bị hoại tử

\subsubsection{Di truyền tính chống chịu thuốc diệt cỏ trong cây bông chuyển gen}

Dòng bông chuyển gen bar $\mathrm{B} 9$ và $\mathrm{BF} 17$ được lai tạo $\mathrm{F}_{1}, \mathrm{~F}_{2}$ và $\mathrm{BC}_{1} \mathrm{~F}_{1}$ qua 2 bước: Bước 1 , hai dòng được lai với MCU9 (giống thuần thường dùng làm mẹ cho các giống lai) tạo $\mathrm{F}_{1}$, sau đó tự thụ tạo $\mathrm{F}_{2}$ và lai trở lại với MCU9 tạo $\mathrm{BC}_{1} \mathrm{~F}_{1} 1$. Bước $2, \mathrm{~B} 9$ và $\mathrm{BF} 17$ được lai với giống nền không chuyển gen Coker310, sau đó tự thụ tạo $\mathrm{F}_{1}, \mathrm{~F}_{2}$ và lai tạo $\mathrm{BC}_{1}$ được tạo tương tự như trên. Phun Basta $(0,6 \mathrm{~kg}$ ai./ha) lên cây con ở giai đoạn 7 - 8 lá. Theo dõi cây con sống/chết ở giai đoạn 7 ngày sau phun, tỷ lệ sống: chết được dùng để phân tích sự phân ly của gen chuyển.

\subsection{8. Đặc điểm nông sinh học và hình thái}

Thu thập theo phương pháp IPGRI và quy phạm khảo nghiệm DUS của ngành bông, so sánh với đặc điểm giống gốc. Trong đó, thời gian phát dục qua các giai đoạn, tỷ lệ mọc, sức nảy mầm và các đặc điểm hình thái được theo dõi 20 cây/hàng/dòng. Các chỉ tiêu còn lại được theo dõi 10 cây trong số 20 cây trên (đo đếm cách cây, trừ cây đầu hàng và cây mất ngọn).

\section{Kết Quả và Thảo Luận}

\subsection{Chọn lọc các dòng chuyển gen bar thế hệ $\mathbf{T}_{1}$}

Bảng 1 thể hiện kết quả của 17 dòng bông chọn được từ 116 dòng bằng thử tính chống chịu thuốc diệt cỏ (Hình 1). Các cây bông chọn được đánh giá sự hiện diện của gen chuyển bảng PCR (Hình $2 \mathrm{~A}$ ), xác định số bản sao gen chuyển bằng Southern blot (Hình $2 \mathrm{~B}, \mathrm{C}$ ) và xác định sự biểu hiện của gen chuyển bằng Northern blot (Hình $2 \mathrm{D}$ ).

Xử lý Basta 15SL (nồng độ 0,6 kg ai./ha) ở giai đoạn 4 - 5 lá cho 47 dòng mang gen pCB301: bar thu được 18 dòng có cây chống chịu glufosinate, nhưng tỷ lệ cây sống rất thấp. Mức độ chống chịu của các dòng đều từ yếu - trung bình (cây có khả năng phục hồi). Năm dòng chọn CB3, CB15, CFB2, CFB6 và CFB18 có tỷ lệ sống 7,1 - 21,4\% (Bảng 1 ) và mức độ chống chịu tốt hơn cả và cây dễ hồi phục (Hình 1E).

Xử lý Basta 15SL (nồng độ $0,6 \mathrm{~kg}$ ai./ha) ở giai đoạn $4-5$ lá cho 69 dòng $\mathrm{T}_{1}$ chuyển gen pCAMBIA: bar thu được 48 có cây chống chịu glufosinate ở mức trung bình- rất cao. 12 dòng chọn (Bảng 1) có tỷ lệ cây sống 32,4 - 81,4\%, cây chống chịu rất cao (Hình $1 \mathrm{~F}$ ). Đối với các dòng có tỷ lệ sống: chết xấp xỉ 3:1 tương đương tỷ lệ dự kiến cho một gen trội duy nhất trong quần thể tự thụ phấn.

Việc áp dụng một loại thuốc diệt cỏ như glufosinate có thể gây ra các phản ứng nhạy cảm khác nhau trong cỏ dại, chủ yếu là do tính biến đổi di truyền rộng của chúng. Sự nhạy cảm khác nhau có thể được giải thích bằng sự khác biệt trong chuyển vị, hấp thu và chuyển hóa thuốc diệt cỏ (Everman \& ctv., 2009). Bên cạnh đó, các yếu tố dẫn đến di truyền phi Mendel là kiểu gen cây biến đổi do phương pháp chuyển gen, bất thường nhiễm sắc thể, allen không tương đồng, do sự tích hợp gen chuyển không ổn định hoặc im lặng gen chuyển, có thể do tương tác giữa gen chuyển và genome cây nhận (truyền gen kém, trao đổi chéo, không tương hợp nên không có đồng hợp tử) (Zhang \& ctv., 2005).

Để chắc chắn tính chống chịu thuốc diệt cỏ Basta được tạo ra bởi gen chuyển cần kiểm tra sự có mặt của gen bar, kết quả là gen bar có mặt trong cầy chuyển gen thế hệ $\mathrm{T}_{1}$ (Hình $\left.2 \mathrm{~A}\right)$. Kiểm tra sự gắn kết của gen chuyển bằng Southern blot cho thấy 10 dòng chuyển gen giả định là CB3, $\mathrm{CB} 15, \mathrm{CFB} 2, \mathrm{CFB} 6, \mathrm{CFB} 16, \mathrm{~B} 1, \mathrm{~B} 6, \mathrm{~B} 9, \mathrm{~B} 18$ và BF17 mang 1 bản sao, 2 dòng B2, B4 mang 2 bản sao. Trên đối chứng không chuyền gen Coker310, không phát hiện băng lai (Hình 2B, C). Kết quả này cũng xác nhận kết quả $\mathrm{PCR}$ và chỉ ra sự tích hợp của vùng T-DNA trong gemome cây chuyển gen. Sự xuất hiện băng lai giữa mẫu dò là cDNA từ cây chuyển gen với RNA tổng số của 6 dòng CB3, CB5, B2, B8, B9 và BF17 (Hình 2D) cho thấy có hoạt động phiên mã của gen chuyển.

Thử nghiệm sinh học về khả năng chịu thuốc diệt cỏ ở cả cây chuyển gen và không chuyển gen thế hệ $\mathrm{T}_{2}$ cũng được áp dụng với Basta 15SL. Lá của những cây không được biến đổi gen bị cháy (Hình 3C), trong khi những cây của cây biến đổi gen không có triệu chứng như vậy (Hình 3B). Hình 3A cho thấy, trước khi phun thuốc cây 
Bảng 1. Số cây mọc, số cây sống, tỷ lệ (\%) cây chống chịu Basta 15SL của 12 dòng bông chọn

\begin{tabular}{clcccc}
\hline TT & Dòng bông & Số cây mọc & Số cây sống & Tỷ lệ cây sống (\%) & Mức độ \\
\hline 1 & CB3 & 112 & 8 & 7,1 & +++ \\
2 & CB15 & 95 & 11 & 11,6 & +++ \\
3 & CFB2 & 73 & 11 & 15,1 & +++ \\
4 & CFB6 & 107 & 15 & 14,0 & +++ \\
5 & CFB18 & 42 & 9 & 21,4 & +++ \\
\hline 1 & B1 & 132 & 82 & 62,1 & +++++ \\
2 & B2 & 16 & 13 & 81,3 & ++++ \\
3 & B3 & 84 & 59 & 70,2 & +++++ \\
4 & B4 & 42 & 34 & 81,4 & ++++ \\
5 & B6 & 66 & 45 & 68,2 & ++++ \\
6 & B9 & 198 & 142 & 71,7 & +++++ \\
7 & B18 & 111 & 36 & 32,4 & +++++ \\
8 & B20 & 36 & 32 & 62,8 & ++++ \\
9 & BF8 & 102 & 52 & 51,0 & +++++ \\
10 & BF12 & 91 & 36 & 39,6 & ++++ \\
11 & BF17 & 82 & 42 & 51,2 & ++++ \\
12 & BF25 & 42 & 30 & 71,4 & +++ \\
\hline & Coker310 & 35 & 0 & 0 & - \\
\hline
\end{tabular}
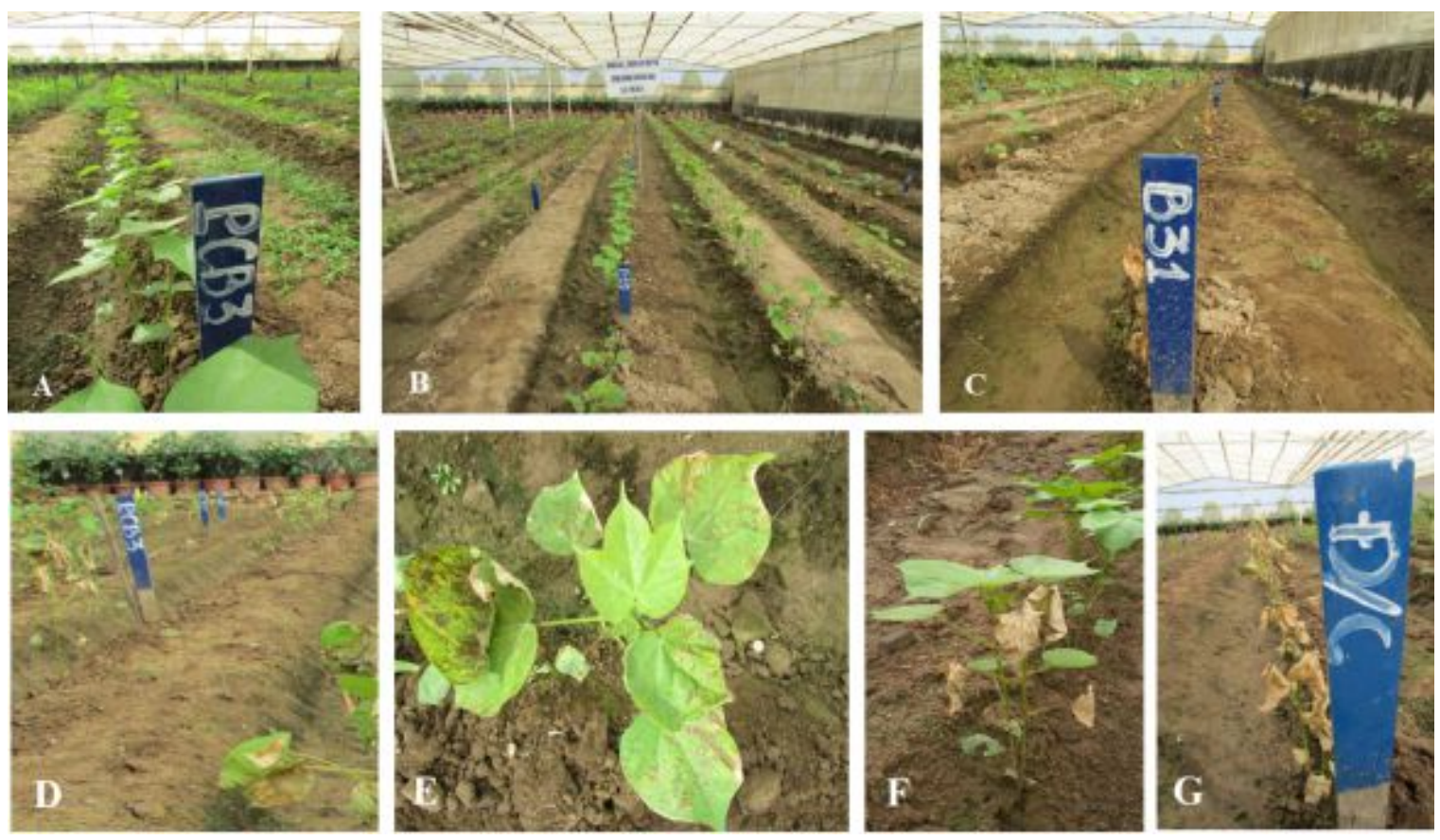

Hình 1. Cây bông chuyển gen bar thế hệ T1 trước và sau khi xử lý thuốc diệt cỏ cỏ Basta 15SL (nồng độ $0,6 \mathrm{~kg}$ ai./ha), triệu chứng sau xử lý 5 ngày ở giai đoạn 4 - 5 lá.

A: Trước khi xử lý; B: Sau xử lý thuốc diệt cỏ; C: Cây không chống chịu; D, E: Cây chống chịu thuốc diệt cỏ ở mức kém; F: Cây chống chịu thuốc diệt cỏ ở mức cao; và G: đối chứng không chống chịu.

bông và cỏ phát triển rất tốt, sau phun Basta với nồng độ $0,6 \mathrm{~kg}$ ai./ha làm cho cỏ và đối chứng là Coker310 chết hoàn toàn (Hình $3 \mathrm{C}$ ) và cây bông không bị ảnh hưởng (Hình 3B). Mức độ chống chịu của các dòng có khác nhau, chống chịu cao (Hình $3 \mathrm{D}$ ) và chống chịu trung bình (Hình $3 \mathrm{E}$ ). 

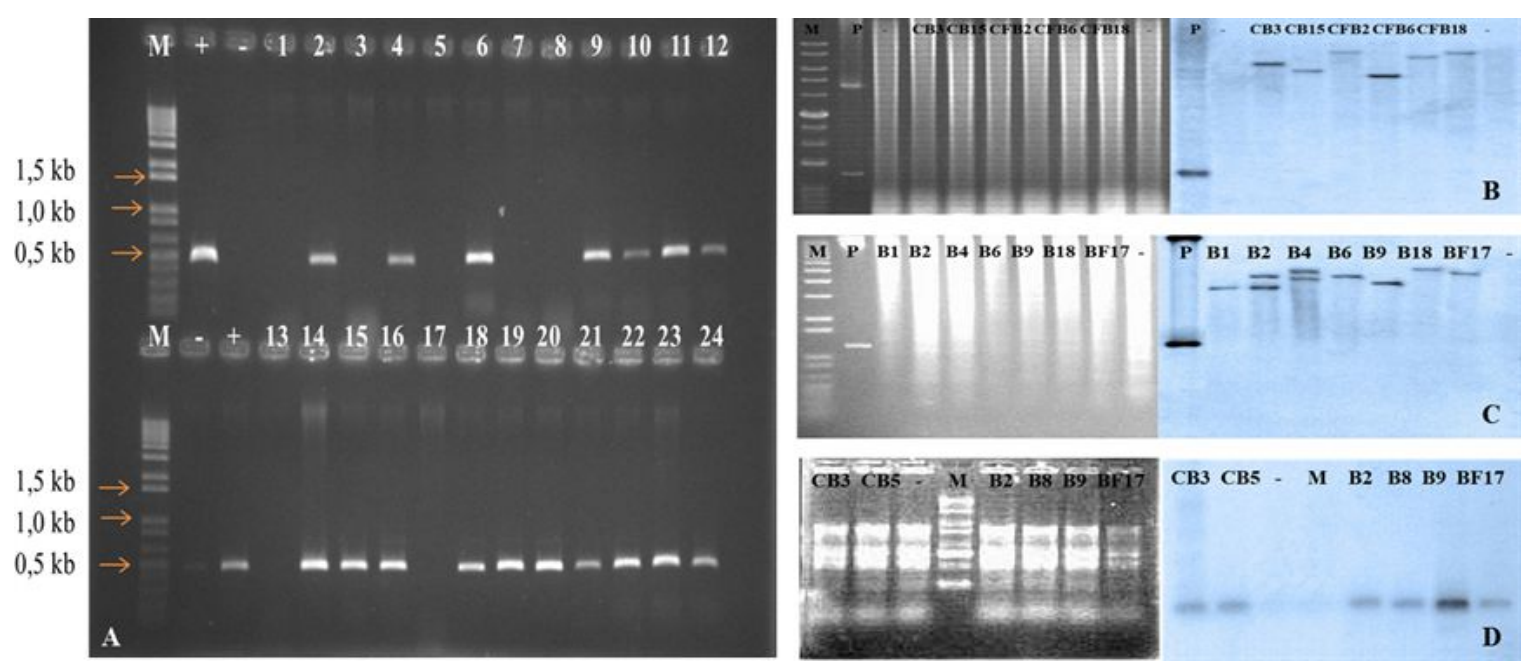

Hình 2. Đánh giá các dòng bông chuyển gen bằng kỹ thuật sinh học phân tử.

A: Sản phẩn PCR gen bar trong cây chuyển gen. M: thang DNA chuẩn; $(+)$ : plasmid pCAMBIA1300: bar; (-): Coker310; 1-24 cây chuyển gen.

B: Southern blot. (M): thang DNA chuẩn 1kb; P: plasmid pCB301: bar/PstI (+) EcoRI; 1: (-) Coker310; CB3, CB15, CFB2, CFB6 và CFB18: dòng chuyển gen.

C: Southern blot. (M): thang DNA chuẩn; P: plasmid pCAMBIA: bar/PstI (+) EcoRI; B1, B2, B4, B6, $\mathrm{B} 9$, $\mathrm{B} 18$ và $\mathrm{BF} 17$ : dòng chuyển gen; (-): Coker310.

D: Northern blot. $(\mathrm{M})$ : thang RNA chuẩn 0,5 kb; CB3, CB5, B2, B8, B9 và BF17: dòng chuyển gen; (-): Coker310.
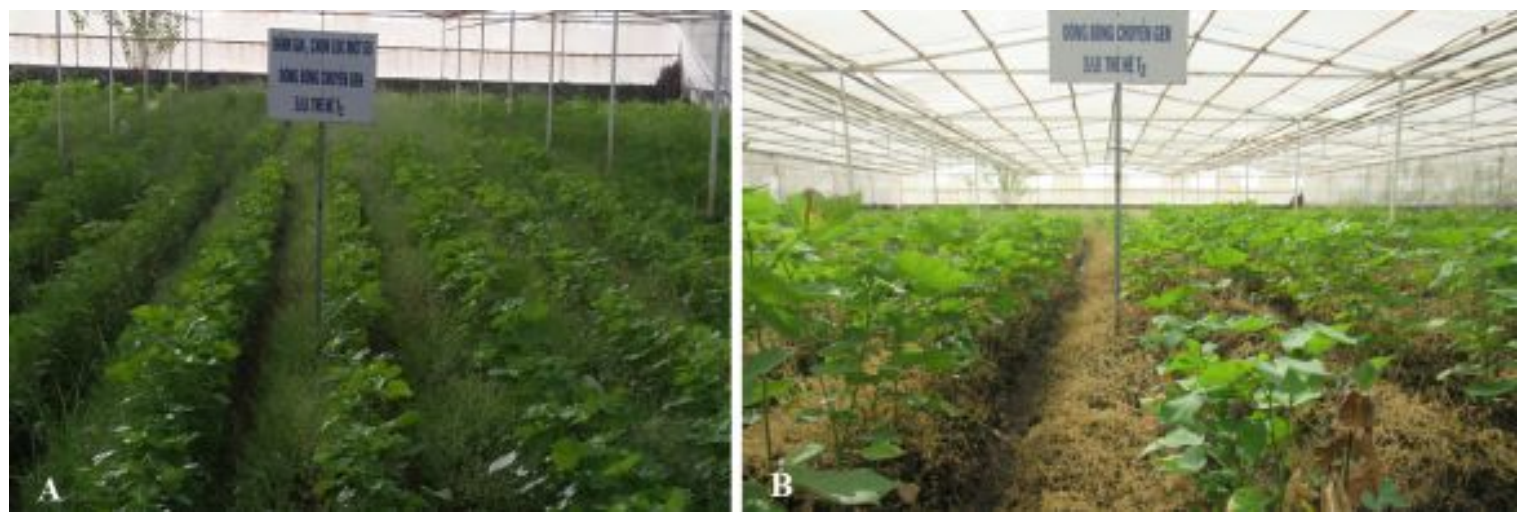

Hình 3. Dòng bông chuyển gen bar thế hệ $\mathrm{T}_{2}$ xử lý Basta ở giai đoạn $7-8$ lá, liều lượng $0,6 \mathrm{~kg}$ a.i $/ \mathrm{ha}$. (A) trước khi phun, (B) sau phun 7 ngày.

Năm dòng $\mathrm{B} 1, \mathrm{~B} 9, \mathrm{~B} 18$ và $\mathrm{BF} 8, \mathrm{BF} 17$ thể hiện mức độ chống chịu cao và ổn định.

\subsection{Di truyền tính chống chịu thuốc diệt cỏ của các dòng chuyển gen $b a r$}

Để làm sáng tỏ sự di truyền tính trạng chịu thuốc diệt cỏ của dòng $\mathrm{B} 9$ và $\mathrm{BF} 17$, phân tích di truyền cho tính trạng này đã được thực hiện. Các tổ hợp lai $\mathrm{F}_{1}$ được tạo ra là $\mathrm{B} 9 \times \mathrm{MCU} 9, \mathrm{MCU} 9 \times \mathrm{B} 9, \mathrm{~B} 9 \times$ Coker 310 và Coker $310 \times$ B9 chống chịu hoàn toàn với glufosinate (Bảng 2). Chứng tỏ rằng tính trạng chống chịu là trội và không bị ảnh hưởng bởi di truyền theo dòng mẹ (Zhang \& ctv., 2005). Quần thể $\mathrm{F}_{2}$ B9×MCU9 phân ly theo tỷ lệ chuẩn 3:1. Phân ly sống chết ở quần thể F2 từ cặp lai Coker310 ×B9 cũng đã xác nhận tỷ lệ xấp xỉ 3:1 $\left(\chi^{2}=0.008\right)$. 
Bảng 2. Phân ly tính chống chịu thuốc diệt cỏ của dòng bông B9

\begin{tabular}{clcccc}
\hline TT & Cặp lai & Tổng cây & Tỷ lệ cây sống $(\%)$ & $\begin{array}{c}\text { Tỷ lệ phân ly } \\
\text { sống: chêt }\end{array}$ & $\chi^{2}$ \\
\hline 1 & B9 $\times$ MCU9 (F1) & 30 & 100 & & \\
2 & MCU9 $\times$ B9 (F1) & 96 & 100 & & \\
3 & B9 $\times$ Coker 310 (F1) & 52 & 100 & & \\
4 & Coker310 $\times$ B9 (F1) & 37 & 100 & 3,00 & 0,000 \\
5 & B9 $\times$ MCU9 (F2) & 48 & 75,0 & 3,25 & 0,059 \\
6 & MCU9 $\times$ B9 (F2) & 51 & 76,5 & 3,30 & 0,070 \\
7 & B9 $\times$ Coker 310 (F2) & 43 & 76,7 & 2,91 & 0,008 \\
8 & Coker310 $\times$ B9 (F2) & 43 & 74,4 & 1,05 & 0,023 \\
9 & (B9 $\times$ MCU9) $\times$ MCU9 & 43 & 51,2 & & \\
10 & (B9 $\times$ Coker 310) $\times$ Coker 310 & 41 & 51,2 & & \\
\hline $\mathrm{P}_{0,05}=3,841$. & & & &
\end{tabular}

Bảng 3. Phân ly tính chống chịu thuốc diệt cỏ của dòng bông BF17

\begin{tabular}{|c|c|c|c|c|c|}
\hline TT & Cặp lai & Tổng cây & Tỷ lệ cây sống (\%) & $\begin{array}{l}\text { Tỷ lệ phân } \\
\text { ly sống: chết }\end{array}$ & $\chi^{2}$ \\
\hline 1 & BF17 × MCU9 $(\mathrm{F} 1)$ & 53 & 100 & & \\
\hline 2 & MCU9 $\times$ BF17 $(\mathrm{F} 1)$ & 75 & 100 & & \\
\hline 3 & BF17 $\times$ Coker $310(\mathrm{~F} 1)$ & 37 & 100 & & \\
\hline 4 & Coker310 × BF17 $(\mathrm{F} 1)$ & 71 & 100 & & \\
\hline 5 & BF17 × MCU9 $(\mathrm{F} 2)$ & 49 & 77,6 & 3,45 & 0,170 \\
\hline 6 & MCU9 × BF17 (F2) & 43 & 72,1 & 2,58 & 0,194 \\
\hline 7 & BF17 $\times$ Coker $310($ F2) & 55 & 76,4 & 3,23 & 0,055 \\
\hline 8 & Coker310 × BF17 (F2) & 33 & 78,8 & 3,71 & 0,253 \\
\hline 9 & $(\mathrm{BF} 17 \times$ MCU9 $) \times$ MCU9 & 38 & 52,6 & 1,11 & 0,105 \\
\hline 10 & $($ BF17 $\times$ Coker 310$) \times$ Coker 310 & 43 & 51,2 & 1,05 & 0,023 \\
\hline
\end{tabular}

$\mathrm{P}_{0,05}=3,841$.

Tỷ lệ phân ly của quần thể hồi giao $\mathrm{BC} 1 \mathrm{~F} 1$ $(\mathrm{B} 9 \times$ MCU9 $) \times$ MCU9 và $(\mathrm{B} 9 \times$ Coker310 $) \times$ Coker310 đều là $1: 1$, khi phân tích $\chi^{2}$. Như vậy, kết quả từ các cặp lai khác nhau đều chỉ ra mô hình di truyền đơn gen.

Kết quả ghi nhận ở Bảng 3 cho tỷ lệ phân ly sống: chết phù hợp dự đoán ở $\mathrm{F}_{2}$ là $3: 1$ và $\mathrm{BC} 1 \mathrm{~F} 1$ là $1: 1$, giá trị 2 đều nằm trong khoảng cho phép. Do đó, dòng BF17 cũng có mô hình di truyền đơn gen.

Kết quả phân ly tính kháng hỗ trợ kết luận cassette biểu hiện protein bar trong 2 dòng bông B9 và $\mathrm{BF} 17$ là một bản sao phù hợp cho mục tiêu tạo giống chống chịu thuốc trừ cỏ gốc glufosinate. Bởi vì dòng Coker không được trồng phổ biến, tính trạng chống chịu phải được chuyển qua các giống có năng sất cao hơn, thích nghi tốt hơn bằng phương pháp lai trở lại (Perlak \& ctv., 1990). Kết quả này cũng khẳng định, gen chuyển trong dòng $\mathrm{B} 9$ và $\mathrm{BF} 17$ đã ở dạng đồng hợp tử, phù hợp với mục tiêu lai tạo.

\subsection{Di truyền gen chuyển và đặc điểm nông sinh học của cây chuyển gen thế hệ $\mathbf{T}_{2}$}

Các đánh giá về kiểu hình, đặc điểm nông học giữa cây trồng chuyển gen và cây trồng truyền thống không chuyển gen có thể hỗ trợ kết luận có hay không nguy cơ trở thành cỏ dại, dịch hại có thể xâm lấn của cây trồng chuyển gen so với cây trồng truyền thống. Trong trường hợp dữ liệu thu được cho thấy không có sự sai khác về các đặc tính đánh giá thì có thể kết luận là cây trồng chuyển gen không làm tăng cường nguy cơ trở thành cỏ dại so với cây trồng truyền thống (OECD, 2008).

Kết quả trong Bảng 4 cho thấy không có sự khác biệt $(P \geq 0,055)$ giữa các dòng bông chuyển gen bar (B9 và $\mathrm{BF} 17)$ với đối chứng Coker310 về các đặc điểm nông sinh học, gồm tỷ lệ nảy mầm, sức mọc mầm, thời gian sinh trưởng từ gieo đến nở hoa, thời gian sinh trưởng từ gieo đến nở quả, số cành quả/cây, số cành đực/cây, vị trí cành quả 1 , khối lượng quả, số quả/cây. Có sự đồng nhất về 
Bảng 4. Đặc điểm nông học, hình thái và tính mẫn cảm với bệnh hại của các dòng bông chuyển gen bar với giống bông nền Coker310

\begin{tabular}{clcccc}
\hline TT & Chỉ tiêu theo dõi & B9 & BF17 & Coker310 & $P$ \\
\hline 1 & Tỷ lệ̀ nảy mầm (\%) & 90,4 & 92,7 & 90,4 & 0,678 \\
2 & Thời gian từ gieo đến nở quả (ngày) & 102,3 & 104,3 & 104,0 & 0,089 \\
3 & Số cành quả/cây & 8,9 & 8,9 & 9,5 & 0,148 \\
4 & Số cành đực/cây & 1,6 & 2,0 & 2,0 & 0,084 \\
5 & Chiều cao cây $(\mathrm{cm})$ & 115,5 & 120,5 & 112,5 & 0,061 \\
6 & Hình dạng thân & Hình tháp & Hình tháp & Hình tháp & - \\
7 & Màu sắc thân & Xanh nhạt & Xanh nhạt & Xanh nhạt & - \\
8 & Màu sắc lá & Xanh TB & Xanh TB & Xanh TB & - \\
9 & Màu sắc cánh hoa & Trắng ngà & Trắng ngà & Trắng ngà & - \\
10 & Màu sắc phấn hoa & Trắng ngà & Trăng ngà & Trăng ngà & - \\
11 & Khối lượng quả (g) & 4,9 & 5,0 & 4,9 & 0,289 \\
12 & Số quả/cây & 10,4 & 10,6 & 11,6 & 0,148 \\
\hline
\end{tabular}

các đặc điểm hình thái (chiều cao cây, hình dạng thân, màu sắc thân, hình dạng lá, màu sắc lá, màu sắc cánh hoa, màu sắc phấn hoa, hình dạng quả) giữa các dòng bông chuyển gen bar với giống nền Coker310.

Trong nghiên cứu này, phân tích $\mathrm{PCR}$ và Southern blot chứng minh đã tích hợp thành công gen bar vào genome Coker310, phân tích Northern blot khẳng định có sự biểu hiện của gen chuyển. Thử Basta cho thấy các dòng bông chuyển gen có mức độ chống chịu cao với glufosinate. Đánh giá thêm các đặc điểm thực vật và nông học trong cả B9, $\mathrm{BF} 17$ và giống nền chỉ ra không có sự khác biệt đáng kể. Ngoài ra, nghiên cứu phân tích tính di truyền đã xác nhận rằng gen bar phân ly theo quy luật Mendel cho đơn tính trạng. Phát hiện này phù hợp với (Khan \& ctv., 2009; Perlak \& ctv., 1990; Zhang \& ctv., 2005).

\section{Kết Luận}

Tính chống chịu thuốc diệt cỏ glufosinate của các dòng bông chuyển gen được duy trì qua các thế hệ $\mathrm{T}_{1}$ và $\mathrm{T}_{2}$.

Chọn được 5 dòng $\mathrm{T}_{2}$ chuyển gen bar B1, B9, $\mathrm{B} 18$ và $\mathrm{BF} 8, \mathrm{BF} 17$ mang 1 bản sao, có hoạt động phiên mã của gen chuyển, cây sinh trưởng đồng đều và có mức độ chống chịu thuốc diệt cỏ glufosinate cao $(0,6 \mathrm{~kg}$ ai./ha).

Hai dòng bông chuyển gen $\mathrm{T}_{2}$ là $\mathrm{B} 9$ và $\mathrm{BF} 17$ mang 01 bản sao gen, di truyền gen chuyển theo quy luật Mendel, chống chịu cao với thuốc trừ cỏ Basta ở nồng độ 0,6 kg ai./ha, không sai khác về đặc điểm thực vật học so với giống bông nền Coker310 không chuyển gen.

\section{Lời Cam Đoan}

Chúng tôi cam đoan không có bất kỳ mâu thuẫn nào giữa các tác giả.

\section{Lời Cảm Ơn}

Nghiên cứu này được tài trợ bởi đề tài "Nghiên cứu tạo giống bông kháng sâu và chịu thuốc trừ cỏ bằng kỹ thuật chuyển gen", mã số KC.06.11/1115.

\section{Tài Liệu Tham Khảo (References)}

Elbaidouri, M., Chaparro, C., \& Panaud, O. (2013). Use of next generation sequencing (NGS) technologies for the genome-wide detection of transposition. Methods in Molecular Biology 1057, 265-274.

Everman, W. J., Thomas, W. E., Burton, J. D., York, A. C., \& Wilcut, J. W. (2009). Absorption, translocation, and metabolism of glufosinate in transgenic and nontransgenic cotton, Palmer amaranth (Amaranthus palmeri), and pitted morning glory (Ipomoea lacunosa). Weed Science 57(4), 357-361.

FAO (Food and Agriculture Organization of the United Nations). (2018). Cotton area harvested and production quality. Retrieved June 12, 2020, from http://faostat.fao.org/site/567/DestopDefault.aspx?P ageID $=567$.

Khan, D., Variath, M., Ali, S., Jamil, M., Khan, M., Shafi, M., \& Shuijin, Z. (2009). Genetic transformation of bar gene and its inheritance and segregation behavior in the resultant transgenic cotton germplasm (BR001). Pakistan Journal of Botany 41, 2167-2178.

Li, H., Luo, J., Hemphill, J. K., Wang, J. T., \& Gould, J. H. (2001). A rapid and high yielding DNA miniprep for cotton (Gossypium spp.). Plant Molecular Biology Reporter 19, 1-5. 
Nha, T. N., Anh, T. V. T., Trang, T. X. V., Trinh, N. U. N., Hai, H. P., Ngoc, B. P., Tri, M. B., Kiem, T. P., \& Hop, M. T. (2016). Efficiency of herbicide resistant gene transformation via A. tumefaciens in cotton plant (Gossypium hirsutum L.). Sciene and Technology Journal of Agriculture and Rural Development 16, 10-19.

OECD (Organization for Economic Cooperation and Development). (2008). Consensus document on the biology of cotton (Gossypium spp.). Paris, France: Organization for Economic Cooperation and Development.
Perlak, F. J., Deaton, R. W., Armstrong, T. A., Fuchs, R. L., Sims, S. R., Greenplate, J. T., \& Fischhoff, D. A. (1990). Insect resistant cotton plants. Bio/Technology 8(10), 939-943.

USDA (United States Department of Agriculture). (2019). Cotton sector at a glance. Retrieved February 12, 2020, from https://www.ers.usda.gov/.

Zhang, Y., Yin, X., Yang, A., Li, G., \& Zhang, J. (2005). Stability of inheritance of transgenes in maize (Zea mays L.) lines produced using different transformation methods. Euphytica 144(1), 11-22. 